\title{
Will You Not Revive Us Again? (Psalm 85:6): An Evaluation of Revival In The Context of Evangelical-Pentecostal Movements
}

\author{
Kwasi Atta Agyapong ${ }^{1}$ \\ ${ }^{1}$ School of Theology and Missions, Pentecost University - Ghana.
}

\begin{abstract}
The study attempted an explanation of what revival of religion is and how revival erupts amongst the Evangelical-Pentecostal movements whiles not leaving behind the challenges associated with the breaking forth of revivals. This qualitative study was guided by the interpretive paradigm and the sampling strategy was homogeneous sampling. The findings are that revivals conjointly originate from the Holy Spirit, through a prepared person. Both the prepared person and the Holy Spirit are requirements for revival to come to pass. Throughout history, revival has occurred with its resultant challenges such as theological incoherence, abuse of gifts, loss of ecclesial identity and distinctiveness. It is being recommended that, revivals should be managed to promote the Christian faith in the long-run. The study has contributed to the literature on revivals by answering the academic argument of whether a revival is a surprising work of God or otherwise.
\end{abstract}

Correspondence:

Kwasi Atta Agyapong

Email: kwasiattaagyapong@

gmail.com

Publication History

Received 16th April 2021,

Accepted 14th May 2021,

Published online 20th May 2021.

Keywords: revival, revivalism, evangelical-pentecostal movements

(C) 2021 The Author(s). Published and Maintained by Noyam Publishers.

This is an open access article under the CCBY license (http://creativecommons.org/licenses/by/4.0/).

\section{INTRODUCTION}

Revival, the continual conversion of the church (inclusive of the people, their policies and logistics) to the full content of the Gospel, has equal biblical and historical precedence. The essential mission of revival must not be limited to ecstasy, faddism or supernatural manifestations, but should be understood as an absolute turn to the cross of Christ and the Gospel of which the Evangelical-Pentecostal movements are the torch-bearers and witnesses to the world. The essence and significance of the Gospel is found in the relevance and the function of believers in the communities. Deprived of such burdens and awareness of becoming relevant to the society, the practice of the Christian faith becomes mere rituals void of applicability and worth.

The word revive, in aorist tense has been used eight times, according to the updated edition of the Strong's Exhaustive Concordance of the Bible. Generally, revive means to be restored, quickened, remain alive, recover, renewed, rejuvenated, awakened and resuscitated. However, the common usage of the noun 'revival' in the title of the study is significant for this discourse as it remains the constant cry of Evangelical-Pentecostals to soothe spiritual atrophy. The unrelenting quests for revivals amongst the Evangelical-Pentecostal movements necessitate the distinction between the words revivalism and revivals. Revivalism is the premeditated cultivation of and preparation for revival. ${ }^{1}$ Revivalism is generally an Evangelical-Pentecostal experience associated with an individual's faith in Christ. ${ }^{2}$ The word revival is not found in the New Testament of the Bible and neither Jesus nor Paul encouraged prayer for revival. Evangelicals argue that revival is not a scriptural word, but asserts that, the phenomenon is described in scripture. ${ }^{3}$ According to Thomas S. Kidd, "revivalism refers to the desire for spiritual renewal in the Church, often including conversion, repentance, and commitment to holiness.... Ordinarily, the concept of revival assumes a Church that was once thriving but has fallen into spiritual decline." ${ }^{4}$

\footnotetext{
Steve Latham, On Revival: A Critical Examination (Carlisle, Cumbria: Paternoster Press, 2003),171-186.

Brian H. Edwards, Revival! A People Saturated with God (Darlington: Evangelical Press, 1990), 27.

Raymond C. Ortlund,Jr., Revival Sent From God:What the Bible Teaches for the Church Today (Leicester: IVP, 2000$), 7$.

Thomas S. Kidd, Cambridge Dictionary of Christian Theology, s.v. "Revivalism." 447- 448.
} 
Revival is an invigorating word for Evangelical-Pentecostal movements; it rekindles the zeal and passion to experience new life, power of the Spirit, renewal, activating the presence of God to perform signs and wonders. Revival is imperative for Evangelical-Pentecostal movements due to spiritual declension and atrophy in their pursuit of God.

The story of Israel in the book of Judges chapters three to sixteen paints a vivid picture of a cyclical spiritual deterioration and subsequent deliverance by God which revives every facet of their worship in what the author calls "the seven sin cycles" in the book of Judges. Israel was trapped in seven distinct vicious cycles of neglect of God or spiritual declension and in all cases, He (God) responded to Israel's cry when they repented of their sins and provided for them a leader to lead the renewal to newness of life when God's freshness (revival) was experienced. The study assesses the impact of selected revivals and recommends how revivals may be controlled to boost the goal or purpose of the church.

\section{METHODOLOGY}

The ontological assumption about social reality in this research is guided by the interpretive paradigm. This assumption is linked to the nominalist school of thought that, social reality has no external existence such that it can be objectively and dispassionately accessed; it is rather the result of human thinking. ${ }^{5}$

The sampling strategy used in this study is Homogeneous sampling which includes sites, people, or incidences because they have common traits or characteristics relevant to what the study is interested in. ${ }^{6}$ Hence, there are many revivals in the Evangelical-Pentecostal movements' context, but they possess similar traits and therefore any or few selected at random can be studied to build a generalized theory to represent the whole. ${ }^{7}$

Many revivals that have transpired in the past are stated briefly for emphasis during the study, but four revivals were sampled and that formed the base for the dialogue, which was selected through the homogeneous sampling strategy.

\section{EXEGESIS OF THE TEXT (PSALM 85:6)}

The book of Psalm is generally seen as God's hymnbook of Praise to Israel. The popular avowal of the Akan in Ghana whenever they read from the Psalm in public worship is Israel dwom transliterated into English as the songs of Israel. ${ }^{8}$

The title of the book, Psalms means praises. The Psalms is a collection of praise songs, hymns and prayers for use in public and private worship services. ${ }^{9}$

Mock theologizes that, the book of Psalm has five main divisions which he categorizes as follows: Chapter 1-41 - Psalm to worship God as the creator; Chapter 42-72 - Worship God as deliverer; Chapter 73-89 - Worship God in His Sanctuary; Chapter 90-106 - Worship God in the wanderings of Life; Chapter 107-150 - Worship God by Obeying His Law. ${ }^{10}$ The Text under review falls under the category of worshipping God in the drifting/wanderings of life. The Israelites understood from their walk with God that, life is full of wanderings, thus both winning and being downcast, being both spiritually equipped and spiritually empty, being both strong and weak as a result of sin. That notwithstanding, they understood that the best to do through the vicissitudes of life is to worship and adore God and hence making a demand on His supremacy to intervene in the affairs of mankind. Chapters 73-89 of the book of Psalms postulates that, when there is spiritually inaptness to depict the glory of God amongst His people, the people of God have no option for restoration other than to seek their God, who alone has the key to renew and invigorate their spiritual vivacity.

The historical setting of Psalm 85 dates back to 536 B.C. when the Jews returned from the Babylonian captivity. ${ }^{11}$ The Northern Kingdom of Israel was taken to captivity in 722/721 B.C., whilst the Southern Kingdom went to captivity in 586 B.C. They were however granted amnesty when Cyrus of Persia allowed the initial group of captives to return in 536 B.C. Psalm 85 is adoration and praise given to God for His deliverance of Israel from Captivity and there is also a prayer for spiritual revivification/revival among the people because there was spiritual declension.

Rendering of Psalm 85:6 in the Hebrew language (Westminster Leningrad Codex):

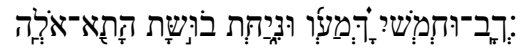

Rendering of Psalm 85:6 from the King James Version: Wilt thou not revive us again: that thy people may rejoice in thee?

\footnotetext{
Gibson Burrell \& Gareth Morgan, Sociological Paradigms and Organisational Analysis (London: Heinemann Educational, 1979).

6 John W. Creswell, Educational Research: Planning, Conducting and Evaluating Quantitative and Qualitative Research, 3rd ed. (New Jersey: Pearsey Education, 2008).

Hinneh Kusi, Doing Qualitative Research: A Guide for Researchers (Accra: Emmpong Press, 2012 )83.

An interview conducted by the author with Mrs. Lucy Agyapong (wife of a Pentecostal Minister) on February 6, 2021 at Nkawkaw.

Dennis J. Mock, Old Testament Survey (Atlanta: Zondervan, 1989), 163.

10 Mock, Old Testament Survey, 163.

11 Roger E. Dickson, Dickson Teachers Bible with Commentary and Encyclopedic Study Guide (Hutchinson, Kansas: African International Missions, 2010$), 663$.
} 
Adam Clark's commentary explains the above text as follows: "We have elongated the verdict of death in ourselves and dreaded an utter extermination. Hereafter, will you not let your people live before you? Shall we not become once more numerous, pious, and powerful?"12

Clark postulates that the Psalmist envisages a time where the enslaved people of God will have an opportunity to live before and become copious and devout in God's presence. The immediacy and presence of God is what the Psalmist was praying for, so they can rejoice in God. Revival brings to the people of God, His glory and manifest presence. In Psalm 85:6, the Psalmist seems to assuage their personal role in the bringing down of revival, by asking or asserting that God should bring to Israel a revival - "thus wilt thou not revive thy people again; that thy people may rejoice in thee?"

\section{EVANGELICAL - PENTECOSTAL UNDERSTANDING OF REVIVAL}

Historians often apply the term evangelical to the churches arising from the Reformation in the sixteenth and seventeenth centuries. ${ }^{13}$ It is not to be equated with any single Christian denomination, for it influenced the existing churches during the eighteenth century and spawned more in ensuing years. ${ }^{14}$

There are basically four qualities or marks that make evangelicalism distinct:

- conversionism- the belief that lives need to be changed,

- activism- the expression of the gospel in effort,

- Biblicism-absolute credence and regard for the bible,

- crucicentrism -emphasis on the sacrifice of Christ on the cross..$^{15}$

Pentecostalism on the other hand refers to churches and movements that emphasize the workings of the gifts of the Spirit, both on phenomenological and on theological premises. ${ }^{16}$ Pentecostals as used in this article refers to all Christians who believe in the workings and gifts of the Holy Spirit. Classical Pentecostals often define themselves in terms of the doctrine of 'initial evidence'- a direct personal experience of God through baptism with the Spirit and evidenced by glossolalia (tongues speaking). Opoku Onyinah avers that,

Pentecostals generally believe that the experience of speaking in tongues is normative for all those who, after conversion, seek a deeper experience in the Holy Spirit. They advocate a Christian life that is receptive to God's power and presence, and the manifestation of all the gifts of the Spirit. From the Holiness background, classical Pentecostals hold that the baptism of the Holy Spirit is the same as the disciples received on the day of Pentecost. ${ }^{17}$

Pentecostals as a movement are mostly concerned primarily with the experience of the working of the Holy Spirit and the practice of spiritual gifts. ${ }^{18}$ The broad use of 'Pentecostal' as used in this article includes the Charismatics and Neo-Pentecostals, that notwithstanding, there are times where charismatics will refer narrowly to Pentecostal experience within 'mainline' churches. Pentecostalism is an attempt to literally worship as was practised by the Apostles in the early church as recorded in the book of Acts. ${ }^{19}$

Evangelical-Pentecostal movements as used in this study means, those Christian groups that-believe in the four distinct marks of evangelicalism and are also concerned or enthused with the workings and practice of the gifts of the Spirit. In relation to conversion experience among the evangelical-Pentecostal movements, they believe that, at conversion, the new believer receives the indwelling presence of the Holy Spirit which is required for thorough salvation to take place. According to the Pentecostals, a subgroup within Evangelicals, there is a further required 'infilling' or 'baptism' of the Holy Spirit which is subsequent to the salvation experience -'second blessing'. One clear distinction between Evangelicals and Pentecostals stems from the interpretation of Luke 3:16 - 'Spirit's Baptism'.

Evangelicals generally equate the Spirit baptism to the salvation experience whiles Pentecostals assert that, the Spirit baptism is a domum superadditum (subsequent experience) after salvation. Pentecostals generally believe that the Spirit baptism is the power to 'witness' and to live the Christian life and also to open the door to a new 'life in the Spirit' which includes the gifts of the Spirit; tongues, interpretation of tongues, prophecy, discernment of spirits, healings, miracles and others as stated in 1 Corinthians 12:1-10. On January 1, 1901, in Topeka Kansas, at Charles F. Parham’s

\footnotetext{
12 Adams Clark Commentary, sv. Psalm 85:6

13 Robert Tudur Jones, The Great Reformation (Leicester: Oxford, 1985),121.

14 David William Bebbington, Evangelicalism In Modern Britain: A History From the 1730s to the 1980s (London: Unwin Hyman Ltd., 1989 ), 1.

5 Bebbington, Evangelicalism In Modern Britain,3.

6 Allan Anderson, An Introduction to Pentecostalism: Global Charismatic Christianity (Edinburgh: Cambridge University Press, 2004$), 13$.

17 Opoku Onyinah, "The Movement of the Spirit Around the World in Pentecostalism," Transformation : An International Journal of Holistic Mission Studies 30, no. 273 (2013), https://doi.org/10.1177/0265378813503234.

18 Robert Mapes Anderson, Vision of the Disinherited: The Making of American Pentecostalism (Peabody: Hendrickson, 1979),4.

19 Andy Lord, "Pentecostal Mission Through Contextualization," Penteco Studies 1 (2011): 103-17.
} 
Bethel Bible College, Agnes Ozman received the Baptism in the Spirit accompanied by the initial evidence of speaking in tongues. She was not the first to speak in tongues in contemporary history as there were episodes of isolated outpourings as early as the 1850s. The uniqueness of Ozman's experience was that it took place in a conscious theological understanding that, baptism in the Spirit is empowerment for ministry and is subsequent to the new birth or salvation experience. ${ }^{20}$ It was under the tutelage of Charles Parham at Bethel Bible College that, the link between the Spirit baptism as an enduement of power and accompanying initial evidence of speaking in tongues was established. ${ }^{21}$

Generally, historical records of revival in contemporary societies feature prominently the operations of the Spirit's gifts and its resultant impact on the lives of people.

It has been generally observed that Evangelical-Pentecostal movements agree that there is revival when the operations of the gifts of the Spirit move vastly among the people resulting in the confession of sins, transformed lives, hyped interest in the things of God, copious proofs of the divine presence and visitations, massive and aggressive evangelization of the gospel.

In the late nineteenth century, in nations around the world, believers were seeking God for a deeper or higher life in Him because of the spiritual decline or loss of the Spirit's fervor.

Menzies in his work asserts that the Methodist church had become successful and in the process of ascending the ladder of pre-eminence and respectability in the society, much of their spiritual fervor and tenacity of the early Methodist had been lost. ${ }^{22}$ Enough lessons may be gleaned from Menzies' assertion to better appropriate and situate revival amid Evangelical-Pentecostal Movements.

Revival shows how different perspectives on the Spirit's outpouring or movement find common ground in evangelism, ministering, and social action..$^{23}$ The perspectives on the Spirit's movements are determined by the Christian tradition one subscribes to. Different Christian traditions emphasize diverse angles of the Spirit's workings: relatively, these perspectives are not conjointly exclusive, they may be viewed as interconnected and integrated. What one tradition applauds generally as the jumbo move of the Spirit might not be emphasized by the other, making the magnitude of the Spirit's outpouring divergent from different viewpoints though inter-related. The Evangelicals accentuate conversions. ${ }^{24}$ The Pentecostals highlight Charismata or gifts to perform signs and wonders. ${ }^{25}$ The Catholic and the Episcopals generally highlight initiations, ${ }^{26}$ whiles the Reformers underscore covenants. ${ }^{27}$ All the perspectives throw light on prevailing Holy Spirit movements in revival.

Evangelical- Pentecostal movements believe that revival is the pouring out of the Spirit of God on all people. ${ }^{28}$ Jesus's messianic prophecies were fulfilled in Luke 4:18 'when the Spirit of the Lord was poured upon Him and He was anointed to preach good news to the poor, deliverance to the captive, restore sight to the blind and to proclaim the year of the Lord's favour or refreshing.' The agency of Evangelical-Pentecostal movements just like the master Jesus shows the powerful nature of the Spirit's power or immediacy which produces an effect that is supernatural and that is revival. Whenever there is revival, there is a literal return to the acts of God in the affairs of man which results in empowering the believers to do the master's bidding (evangelism), unusual commitment to religious activities, activation of supernatural works (signs and wonders), conversion to Christ, and social transformation.

David Martyn Lloyd-Jones, a Welsh Protestant minister and medical doctor who was influential in the Reformed wing of the British evangelical movement in the 20th century defines revival as "an experience in the life of the church when the Holy Spirit does an unusual work. Primarily, revival happens within the church and it generally is the reviving of the believers. You cannot revive what has never had life." ${ }^{29}$ Evangelical-Pentecostal movements postulate that dispirited, slumbering and moribund believers who are in a state of spiritual atrophy when touched by the Spirit's power are brought into a new and a more enlivened state where their spiritual senses become alive. When sluggish believers are thus revived, they are humbled, convicted of their sins, poised to work for Christ and avail themselves for the Holy Spirit to fully possess them. Thus, when revival breaks forth, new grace and unction take hold of the preaching of the gospel and as a result, large numbers outside of the church are converted. Revival generally occurs within a context

\footnotetext{
20 Robert W. Menzies \& Robert P. Menzies, A Call to Evangelical Dialogue:Spirit and Power Foundations of Pentecostal Experience (Grand Rapids, Michigan: Zondervan, 2000).

21 Menzies and Menzies, $A$ Call to Evangelical Dialogue.

22 Menzies and Menzies, A Call to Evangelical Dialogue.

23 Geoff Waugh, Revival Fire: History's Mighty Revivals (Renewal Journal, 2020), 15.

24 James Dunn, Baptism in the Holy Spirit (Westminster: John Knox Press, 1970).

25 Derek Prince, Baptism in the Holy Spirit (Whitaker House, 1995).

26 Michael Green, I Believe in the Holy Spirit (Michigan: WM. B. Eerdmans Publishing Co, 2004).

27 Rodmans Williams, Renewal Theology: Systematic Theology from a Charismatic Perspective (Virginia: Zondervan Academic, 2011).

28 Joel 2:28, (And it shall come to pass afterward, that I will pour out my Spirit upon all flesh; and your sons and your daughters shall prophesy, your old men shall dream dreams, your young men shall see visions, ASV), Acts 2:17, (And it shall be in the last days, saith God, I will pour forth of my Spirit upon all flesh: And your sons and your daughters shall prophesy, And your young men shall see visions, And your old men shall dream dreams, ASV).

29 Martyn Lloyd Jones, "Revival: 'An Historical and Theological Survey'In How Shall They Hear ?," the Compiled Papers from the Puritan and Reformed Studies Conference (London, 1959).
} 
bringing about divine ingenuities, supernatural and ecstatic phenomena, repentance, renewal, healings, manifestations of the Holy Spirit gifts, mass evangelistic meetings accompanied by landslide conversions in a sociological milieu. Thus revival to Evangelical-Pentecostal movements refers to the pouring out of the Spirit of God on people with vivid proofs of supernatural happenings in the sociological context where it occurred. That notwithstanding, the word revival is used as a catchphrase to describe scheduled local church meetings for a period in a local church and that differs from its historical meaning as used in this article.

\section{THE ROLE OF THE SPIRIT IN REVIVAL}

Jesus presents a beautiful picture of understanding the Holy Spirit's movement as this; "the wind blows where it wishes and you hear its sound, but you do not know where it comes from or where it goes ...."(John 3:8, ESV). The allegation of Jesus compliments the polyvalent nature of the subject of the Spirit when it comes to understanding Him from human perspectives. Human engagements with the subject of the Spirit in relation to human experiences expose them to a polyvalent rather than ubiquitous set of voices as almost every individual /denomination may have a differing take on the subject as a result of their experiences and Christian traditions. Amongst Pentecostals only, there are more than one hundred views in relation to believers and glossolalia know-hows.

The work of the Holy Spirit concerning revival comes with a lot of complexities as pneumatological engagements with the human condition project intrenchable hitches. ${ }^{30}$ The text under scrutiny in this study, suggests that revival emanated not from the fold of men, however, it was the cry of a burdened person who requested for a revitalization that will soothe the spiritual emptiness of the people of God.

Evangelicals see revival as God's activity, ${ }^{31}$ thus a visitation or manifestation of the Holy Spirit's presence amongst people..$^{32}$ Evangelical theology accepts revival as a planned and premeditated act of the Holy Spirit to rekindle and spark the urgency of God's activity on earth.

Pentecostals also acknowledge revival as an experience of an abundant outpour of the Holy Spirit. Pentecostals propose that there is revival when the power of God is unleashed amongst people to accomplish signs and wonders with a consciousness of God's presence. Thus prayer meetings become urgent and flourishing, active power evangelism and mission is stimulated, and there is an urgency to live holy. ${ }^{33}$

Consequently, it is glaring that, Evangelical-Pentecostal movements have the belief that, every genuine revival has the Holy Spirit as its source. Revival therefore may not be mimicked or replicated by the design of men as the Spirit of God is the sole architect and engineer of revival. The Evangelical-Pentecostal movements agree with the cry of the Psalmist, "Will you not revive us again (Psalm 85:6)?"

\section{THE ROLE OF PEOPLE IN REVIVAL}

Any activity where it only behooves on the Lord to give without men's participation becomes lurid, as no one may have the gapes to apportion blame when there is slackness in its delivery.

"Break up your fallow ground; for it is time to seek Jehovah, till he comes and rains righteousness upon you" (Hosea 10:12b ASV). The scriptural text brings out the role of men in stimulating the release of the rain of righteousness (revival) from the Holy Spirit. It has been known that revival has its source from God, but it must begin on earth with men. It brings out the exigencies of men, without which revival becomes a delusion. There can absolutely be no revival on earth without men nor the involvement of men. The people of God become chemical agents to revival and as such spiritual ineffectiveness and the Spirits' ebb tide may be attributed to men on earth.

Apostle Eric Nyamekye, Chairman for the Church of Pentecost in his cry for revival publicly on Pent TV, asserted that "if men will, God also wills and if men keep quiet God will also remain mute in the situation." All revivals in history seem to be connected with real men who led the forte and others followed suit thereby igniting the flame of God (revival). Could that suggest that God in His infinite omnipotence cannot bring revival without men? However, God is capable of doing everything, and everything here includes moving men toward a certain end to fulfill His divine purpose. It is men that are revived; God does not need revival and this makes out that, revival always must begin from the camp of men while God remains the source.

\section{The Personality behind the Gold Coast Revival from 1875-1878}

Thomas Birch Freeman, a missionary and minister of the Wesleyan Methodist Church first saw a revival on the Gold Coast (Ghana) from 1851-1852. All the stations of the Methodist church as at the then Gold Coast seemed to have been

\footnotetext{
30 Graham McFarlene, The Role of the Holy Spirit. In On Revival: A Critical Examination (Carlisle, Cumbria: Paternoster Press, 2003).

31 Edwards, Revival! A People Saturated with God,29.

32 Arthur Wallis, Rain From Heaven: Revivals In Scripture and Heaven (London: Sevenoaks Hodder and Stoughton, 1979$) 14$.

33 Austin C. Ukachi, "Marks of a Pentecostal Revival," Sunday Magazine, 2016.
} 
visited by him. Freeman was incessant in the glorious toil and work for his master. Any person who has the passion to accomplish a divine assignment goes the extra mile and does not rest, till the mandate comes to pass, and such was Thomas Freeman. In early October 1875, Thomas Freeman visited Kuntu, an outstation of Anamabu in Ghana, where he found the Christians greatly quickened and in great spiritual expectancy. He wrote: "During the preaching, the people were moved and cried aloud. As they knelt penitently at the communion rail, many trembled exceedingly and clutched the rail to prevent their falling to the floor." ${ }^{34}$ At Elmina, a distinguished service was held - such a meeting had never been known in Elmina said Freeman. The chapel was filled and people stood outside, hard-pressed round the open door and windows. Freeman wrote: "There was a gracious influence resting on the congregation. We invited the penitents to Christ, to which they came in crowds. The Blessed Spirit brooded over us, and we had a fine revival meeting. Scores of the congregation were in tears and crying for mercy and many found peace and joy in believing." ${ }^{\prime 35}$

\begin{abstract}
At Great Kormantine (on the Gold Coast), the people 'cried mightily to the Lord for salvation.'Leaving the chapel, Thomas Freeman preached to the fishermen in the open air, "who were greatly moved by the truths declared' and then retired to the chapel to perform three weddings. One wedding was delayed by a few hours, as in the morning prayer meeting, 'one of the young bride-elect had fallen insensible on the floor under the hallowed fervour....36
\end{abstract}

In early December 1875, Freeman visited Salt Pond (Sailtpond), where the repented who had queued for water baptism, occupied a line of benches forty-seven paces long. On the same day, he returned to Anamabu where two hundred and twelve people were baptized. ${ }^{37}$ On 20 January 1876, Freeman officiated the marriages of five couples and 'baptized two hundred and sixty adults and children... One of the candidates for baptism was the head of a family who was formerly an extravagant drinker of rum, ale, wine and other intoxicants which were connected as part of a ritual with the burial of the dead.' Freeman wrote: 'These are the blessed changes now effected by the operations of the Holy Spirit. ${ }^{38}$ At the end of 1877, at least three thousand people had been added to the Church and fifteen hundred had been baptized by Freeman himself. ${ }^{39}$ Revival writes in history the inexplicable but it must always begin or hinge on a man and such is the Gold Coast revival connected with Thomas Freeman from 1875-1878.

\title{
The Personality behind the Azusa Street Revival from 1906-1909
}

William Seymour, a one-eyed African American from Texas, is the best-known human personality of the Azusa Street revival, but the Holy Spirit was in charge. Some of the other people connected with the Azusa Street Revival were: Charles Parham, Frank Bartleman, William Durham, Joseph Smale, Florence Crawford and Lucy Farrow. ${ }^{40}$ In February 1906, William Seymour moved to a new lodging in the home of Richard Asbery at 214, North Bonnie Brae Street which still exists as a Pentecostal landmark, where he was invited to hold meetings there, and with a small group, they began to fast and pray. A man was healed instantaneously after being anointed with oil by Seymour; after a second prayer, the man began to speak in tongues, then crowds soon congregated to the place of meeting and they had no option than to relocate because the place could no longer hold them. ${ }^{41}$ Revival must start with a man in order to attract men. Revival must not start with angels nor God himself but men, so men would be attracted to it and thereby winning men to the God who anointed the persona behind the revival.

In 1906, Seymour, the negro Holiness preacher and a student of Charles Parham moved the prayer meeting to a two-storey building weatherboard stable and warehouse at 312 Azusa Street which had previously been an African Episcopal Methodist Church on April 14, 1906 and 100 people attended the service including blacks and whites. ${ }^{42}$ Those who trooped to the service were baptized in the Holy Spirit and others received healings. From April 18, 1906, the Los Angeles Times began publishing articles about the weird babble of tongues and wild scenes of the Azusa Street. ${ }^{43}$ The revival did not only project the unusual racial mixture but the critical newspapers reports which drew crowds who crammed to either investigate, mock or join the supposed fanatics which led to hundreds being saved, baptized in the Spirit, healings, evangelistic outreaches and overseas mission. The services ran almost continuously, the place was never closed nor empty within the period; numbers went there to catch the revival fire continually. The meeting did not depend on the human leader but spontaneity was the order, as the Holy Spirit led every aspect of the worship. There was

\footnotetext{
34 Mathew Backholer, Revival Fire: 150 Years of Spiritual Awakenings and Moves of the Holy Spirit Days of Heaven on Earth (Faith Media, 2013).

Backholer, Revival Fire.

Backholer, Revival Fire.

Backholer, Revival Fire.

Backholer, Revival Fire.

Backholer, Revival Fire.

Backholer, Revival Fire.

Waugh, Revival Fire: History's Mighty Revivals, 58.

2 Waugh, Revival Fire: History's Mighty Revivals, 58.

3 Waugh, Revival Fire: History's Mighty Revivals, 58.
} 
no liturgy and none planned what to do in the next couple of minutes or hours, "all was spontaneous and ordered by the Spirit." ${ }^{44}$ At Azusa Street, there was nothing like ecclesiastical hierarchism, educational segregation, and poor/rich man as all were equal.

Historical recordings are yet to present a revival without a personality who spearheaded the move for others to join. Wherever there is revival, there is a man who has availed himself to be used by God. Revivals conjointly emanate from the Holy Spirit through men/women who have been prepared and have a burden to stand in the gap to bring the presence of God to the fold of men.

\section{DOES REVIVAL QUICKEN OR DEADEN A CHURCH?}

Revival in itself is the desire of Evangelical-Pentecostal movements and the thoughts of revival bring times of refreshing and gladdens their hearts. The impact and experience are soothing and the author seeks to unravel whether, in the long run, it quickens or deadens the church? Most Christians never get more excited than when revival is mentioned. Is revival a fad, fashion, or fantasy? Does it build the church or slacken its groundwork.

The present malaise and cry of Evangelical-Pentecostal movements is to be revived due to spiritual atrophy and droopiness in Christendom. The cry is essential, instinctual and leading the church to flip-flop in disproportion, against which the prayer for the Holy Spirit to revive the church is not only fitting but indispensable. ${ }^{45}$ The question to resonate on is how the esteemed revival culminates in the sustenance of the Evangelical-Pentecostal movements?

Since there was a precedence of revivals in history, the aftermath of some of these revivals in times past may be evaluated to understand whether it grows the church or stifles the church's existence in the long run. The author understands that it is readily assumed that, the purpose of revival is to enliven or quicken the church and as such much desirable. However, because it is a human experience, it is a more ambiguous affair and that in some aspects and sometimes it may serve to do the opposite by compounding the church's spiritual ineffectiveness. ${ }^{46}$

\section{Welsh Revival}

The Welsh revival was the prime Christian revival in Wales during the $20^{\text {th }}$ century. The revival began through an effort to kindle non-denominational, non-sectarian spirituality which was ignited from 1904-5. The revival arose with the rise of the labor movement, socialism and a general disaffection with religion among the working class and the youth. The story of the Welsh revival and Evan Roberts seems intertwined as he was the catalyst used by God to spearhead the revival. The visitation of the Holy Spirit was widespread and ubiquitous in the country of Wales and the revival was felt everywhere.

During the period of the revival, there were thousands of testimonies of hardened souls receiving salvation and lives that were changed for Christ became the talk of the town. The impact and presence of the Lord were evident in many lives. Stories of profanity were silenced, theatres were deserted, courts were also abandoned due to lack of crime, pubs folding up became a commonplace event, football matches could not compete with the presence of the glorious visitations. The revival became so prominent and impacting that, the Western Mail Newspaper in Cardiff, published Revival Editions as it was what the people wanted to read and monitor. The launch of the revival was enunciated by a strong sense of conviction of sin, with transgressions visibly confessed. Instead of sports and other mundane items, the hot topic in the pubs was about Evan Roberts and the Welsh revival. The Western Mail newspaper stated that "the only theme of conversation among all classes and sects is Evan Roberts. ${ }^{\prime 77}$ Drunkenness was cut in half, causing bankruptcies in many pubs and social activities. The spate of criminal activities was cut in half. Anterior abodes of prostitutes turned into homes of heavenly melodic voices, encouraging their former customers to go to the revival meetings. The Bible Society in Wales could not keep up with the demand for Bibles. People began to pay off their bad debts. Some of the toughest characters in the Welsh valleys were converted. Pit-ponies could no longer understand the miners' commands as they had stopped cursing the ponies. ${ }^{48}$ The police, often having no one to arrest, would come to the revivals to sing in quartets. In one court case, the prisoner came under conviction, confessing his sins. The judge then preached the gospel to him, and the jury spontaneously broke out into Welsh revival singing. Gomer M. Roberts commented, "Who can, but give an account of the lasting blessings of the 1904-5 revival? ${ }^{49}$

In spite of the pince-nez of the Welsh revival, there is evidence to confirm the fact that, the century after the Welsh revival has witnessed a phenomenal decline of Christianity, to the extent that Wales is regarded as one of the least Christian countries in Europe. ${ }^{50}$ Is there an allusion as to why the thousands of people won into the church as a result

44 Waugh, Revival Fire: History's Mighty Revivals, 59.

45 Ian Stackhouse, Revivalism, Faddism and the Gospel In On Revival: A Critical Examination (Carlisle, Cumbria: Paternoster Press, 2003 ),239.

46 Nigel Wright, Does Revival Quicken or Deaden a Church? In On Revival : A Critical Examination (Carlisle, Cumbria: Paternoster Press, 2003),121.

47 Awstin ( The Principal Western Mail Reporter), The Religious Revival in Wales, (London: Revival Library Reprints, 1904$), 2$.

48 Dr J Edwin Orr in a lecture given at First Baptist Church of Garland, Texas, November 1985.

49 Rev. Dr. Ed and Janice Hird, “An Analysis of Evan Roberts and the Social Impact of the 1904 Welsh Revival,” Light Magazine, June (2019).

50 Wright, Does Revival Quicken or Deaden a Church. 
of the revival could not sustain the numerical and spiritual fervency of the Wales churches? How flawless will it be to answer the question of whether revival accelerates or dampens a church?

\section{Revival associated with Watchman Nee's ministry in the 1930s}

Angus Kinnear's biography of the Chinese Christian leader, Watchman Nee in the 1930s reports a period of spiritual revivification over a year or two on spiritual experiences, ecstasy and subjective experiences. ${ }^{51}$ This revival prominently featured, clapping, incessant laughter, glossolalia experiences, jumping, a deluge of sensual and dramatic healings some undoubtedly real but not a few mistaken. ${ }^{52}$ Kinnear put down Nee's judgment on the revival portents that, some revivalistic approaches worked like spiritual opium and obsession to them compelled a continually cumulative dosage. Nee's forfeiture of restraint led to his valuation of the revival after three years as follows: 'we find on looking back that, the gains have rather been trivial, the loss large'. ${ }^{53}$ The assessment of the Nee's revival in the 1930s suggests a kind of reversion to the much sought for revival, by the Evangelical-Pentecostal Movements. It initiates a kind of dialogue on how an anticipated effervescence can just diminish, thereby causing a grander loss than the gains. This will invigorate the probes of whether the revival was worthwhile in the first place or a miniature quench to the dehydration of Evangelical-Pentecostal Movements.

\section{LESSONS FOR THE FUTURE}

\section{- Revival and Theological Incoherence}

When there is revival, very often new theologies emerge with them which need to be weighed holistically in the light of scriptures. It should be realized that whatever supernatural occurrences take place cannot do away with scripture. Experiences in themselves should not be seen as paramount but scripture should be the standard that delimits and interprets any dogma that emerges when revival breaks forth.

Charles Parham and the others who laid the foundations of the doctrine of the Holy Spirit baptism which unfolded in the Azusa Street revival initially understood that the tongues received were gifts of other languages (Xenolalia) for the world evangelization mission which is theologically incoherent with scriptures. ${ }^{54}$ Xenolalia is a language that is alien to the speaker but familiar or understood by the hearers. It implies that revivals though genuine, have the muscle to produce defective theology if not checked.

Revival tends to make room for human experiences to determine the understanding of God (theology), which in reality must not be encouraged. Understanding of God is determined from the revelations of scripture. Human theologies and dogmas must be firmly grounded upon scripture and not experiences that have the tendency of spurring theological incoherence.

Evangelica-Pentecostal movements' theology must not be formulated to suit new trends or adjusted to meet the emerging new ideas and philosophies of current times as there is the tendency to produce syncretic theologies which inadvertently overwhelm revivals. The theologies of Evangelical-Pentecostal movements should devise comprehensive theologies firm enough to alleviate the contextual challenges that emerge from revival contexts. "In developing a theological response to a religious challenge, the phenomenon and the context being studied is subjective to the Scripture which is objective, whiles not thrashing wholly all the elements in the context." 55

\section{- Absolute Neglect of Rationalism}

According to the Merriam Webster dictionary, rationalism is the reliance on reason as the basis for the establishment of religious truth. Religious truth can best be determined through revelation from scripture other than from human rationality. That notwithstanding, the conscience of children of God are thus renewed with the truth of the scripture to reason on religious truths, thereby making faddism, religious jargons, superstitions and unreasonable ecstasy of no effect. Many people are of the hope that when revival breaks forth all efforts of men become null and void and everything directed, is by the Holy Spirit. The study has presented some revivals in history where all human activities were left to spontaneity as it was believed that, the Spirit of God directs all as He wills without human involvement. The Lord created the Garden of Eden, thus the first revival center, and made man the CEO of the garden. He instructed the man to work on it and keep it. Man can only work on the garden because he is a rational being. Absolute neglect of rationalism casts an indictment on God's image (man) as if man becomes a robot when revival breaks forth through

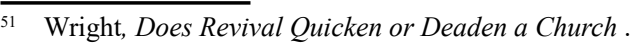

52 Angus I. Kinnear, Against the Tide: The Story of Watcman Nee (Eastbourne: Kingsway, 1973),134.

53 Kinnear, Against the Tide, 135.

54 Waugh, Revival Fire: History's Mighty Revivals, 59.

55 Kwasi Atta Agyapong, "Pastoral And Theological Responses To The Effects Of Witchcraft Beliefs In Ghana," E-Journal of Humanities, Arts and Social Sciences (EHASS) 1, no. 5 (2020): 174-84, https://doi.org/https://doi.org/10.38159/ehass.2020096.
} 
absolute neglect of his rightful responsibility. Over reliance on rationalism will lead to secularism, ${ }^{56}$ whiles absolute neglect of rationalism is faddism which parallels the unfaithful servant who buried his talent to his own detriment as narrated in Matthew 25:25. Revival must not necessarily rob man of his/her renewed conscience and reason.

\title{
- Forfeiture of Ecclesial Distinctiveness
}

The most cunning consequence of theoretical revivals is the way it fosters an exhortatory mode of homily and has utter disregard for doctrinal and doxological language. The most vital factor in ecclesiology distinctiveness must not be hinged primarily on any other than the doctrines and liturgy. Most Evangelical-Pentecostal revivals thrive on motivational rather than revelatory theories and as a result, may lose touch with their distinctiveness from their roots or foundation. The incessant conversion of the church to the language of her own gospel is the crucial mission of revival and deviation is detrimental to the sustenance of the church. All church traditions have the gospel to preach as well as the liturgy to make out their uniqueness.

A comprehensive study of historical and biblical precedence's of revival seems to rubbish important doctrines and liturgies which have long sustained the church to new motivations as a result of perceived revivals and subsequent enlightenment. It's glad that God refreshes His church and blows in fresh air which needs to clear the cobwebs which might have sustained the church but currently irrelevant or impeding the growth of the church. That notwithstanding, 'the baby must not be thrown out with the bathwater.' Evangelical -Pentecostal movements must realize that Jesus Christ in Matthew 13:52 asserts that, every scribe well instructed in the kingdom of God, brings forth out of his treasure, things that are new as well as old. Revivals must not necessarily and discriminatorily do away with all supposed antiquated liturgies even when they are not salvific as they often serve as factors to make distinct the church movement. That does not also suggest that adjusting an unwholesome liturgy whose expediency is outlived is a discredit.

\section{- Quest for Ultimacy}

By the 1980s many empire-building evangelicals had shifted their emphasis for the truth of the gospel that endures and establishes Christians to successes of churches per their standards. ${ }^{57}$ The focus of Evangelical-Pentecostal has gradually drifted from parousia (second coming) of Christ to the building of megachurches and the achievement of the church. Emphasis on churches seems to have displaced the savior of the church and the focus is currently on the church herself and as result, unhealthy competition abounds amongst various Christian traditions and movements as to who is making the greatest impact. This syndrome is clearly portrayed from the prayers of some Evangelical-Pentecostal movements who anticipate revival as was also found in the assertion of Joel Edwards:

\begin{abstract}
The nation will hear our biblical voice and acknowledge the role of Christianity in its midst. Many will turn to Jesus through our witness in words and deeds. Policy-makers will take account of our values, rather than increasingly attacking them. The door to the gospel will swing open as people as forced to notice the evangelical factor. ${ }^{58}$
\end{abstract}

It should, however, be realized that the church herself is not the end, but a means to an end and the quest for ultimacy in favour of church traditions and dogmas could also mean relegating the owner of the church to the background, where He is given the second place in the order of prominence and attraction. Evangelical-Pentecostal Movements must not pre-empt unusual ecstasies or spirituality which their Lord has not ordained to advance their superiority or supposed relevance. It was realized from the study of revivals that, those revivals which epitomized building an agenda for a particular strand of society within the Christendom cannot be found now. The church is the tool used by God to save the world and a proper understanding will cause the church to promote the God of the church whiles the God of the church inadvertently energizes His tool (the church) to continually become significant to lead the world to Him.

\section{- Ecstasy, Fantasy, and Religious Jargons (thus copycatting revivals)}

Ecstasy during revival entails spontaneous surrender to an intense physical, emotional and psychological response to depict an urgent sense of the presence of God. Some of the common ecstatic phenomenon amongst EvangelicalPentecostal Movements is falling over, trembling, weeping and laughter which is generally understood as the immediacy of God's presence amongst men. Ecstatic spirituality has a life cycle according to Rob Warner. When the people surrender to ecstasy and fantasies, the next phase seems contagious as most people mimic or copy the spectacle which leads to

56 Kwasi Atta Agyapong, "Beliefs in the Activities of Witchoraft in Ghana," E-Journal of Religious and Theological Studies -5th Anniversary Special Edition 6, no. 6 (2020): 281-89, https://doi.org/https://doi.org/10.38159/erats.2020092.

57 Rob Warner, Ecstatic Spirituality and Enterpreneurial Revivalism: Reflections on the Toronto Blessings In ON Revival - A Critical Examination (Carlisle, Cumbria: Paternoster Press, 2003).

58 Joel Edwards, Evangelical Alliance: Euston Statement on the Toronto Blessing Reprinted in Calver, C. and Warner, R. (1996. Together We Stand (London: Hodderand Stoughton, 1994). 
standardized responses. If it is falling, it becomes as if many become programmed and conditioned for the move to depict a touch from God. During the days of Toronto Blessing Revival from 1994-7, attendants to the services were later lined up with sufficient space between the rows to allow for normative prostrations or falling 'under the anointing'. ${ }^{59}$ Ecstatic phenomena have a tendency of creating a hierarchy of physical, emotional and psychological responses, where people will have to graduate to the next level of ecstatic capitulation. Warner asserts that at the Toronto Blessing revival people were thus encouraged to return for further prayer not only to listen to God's word or 'soak in God' but to move to the next phase of the ecstasy, fantasy or religious gobbledygook. "Additionally, delusions being a mental disorder in psychiatry can make an individual subscribe to beliefs that are not true." ${ }^{6}$

This accounts for the recent canker in churches, where people will always look for new ways of heightening participant's interests and devising new fantasies to depict a kind of growth to a higher phase of the ecstatic spirituality. It should, however, be realized that ecstasy cannot be sustained as a normative practice and that accounts for its apparent graduation to sustain members. That notwithstanding, any person will become bored with repeated experiences/ responses. People naturally become wearied with demands of spiritual aerobics exemplified in the flesh which fails to give the needed inner drive or change and as a result become disillusioned. Lessons for Evangelical -Pentecostal movements is that ecstasy, fantasies and religious jargon are mostly copycats to forcibly make happen revivals, which in reality has not happened.

\section{RECOMMENDATIONS}

Revival of religion must conform to scripture and religious jargons, human manipulations and artificial inventions must be detached from the revival itself. The revival should not be seen as the manifestations (glossolalia, shaking, falling down at prayer meetings, incessant continuous laughter, healings, testimonies of people, etc.), as there are possible manifestations as these without it necessarily being revival.

Policies and measures to re-align excesses during revivals must be structured such that, what is meant to streamline the religious mumbo jumbo does not end up annihilating and stifling the flow of the Holy Spirit's move. Most Evangelical-Pentecostal leadership invent dogmas and set systems in place to control the overindulgences, of which most per historical records made transient the revival story. Evangelical-Pentecostal Movements must make lessons out of this when measures to curtail excesses during revivals are set forth.

Revivals from different contexts must not be compared when it comes to the evaluation and assessment of the move of the Holy Spirit, as in a similar vein, horses are not comparable to dogs. When the geopolitics changes, maps are redrawn to suit the changes; different revivals in different contexts will produce different results and manifestations. Thus, copycatting revivals must be discouraged as the Holy Spirit of God is the source of all true revivals and different areas/tangents will be affected at different places at different times whenever different revival breaks forth.

The foundations of revival must be firmly rooted in scripture and deviation from it must be meticulously checked. Jesus Christ must be the ultimate in every revival. Any revival that does not lead people to repentance of sins and confession of Christ is suspicious.

The main characters behind revival movements must not be the focus but Jesus whiles the up and coming generation must also be given the center stage together with the revivalists, so as to maintain the fire for longer periods, because it has been realized that, centuries after most revivals witnessed an abject decline of the Christian faith. Any theory or move projected to last lengthier must be entrusted to the very young ones.

Unnecessary ecstatic and excessive paranormal moods must be checked, worked on and done away with. Revival does not equate to ecstasy, though ecstatic moves may emerge when there is revival. Evangelical-Pentecostal movements believe in the supernatural, but the premium should be given to the gospel, which has the power to produce miracles than to seek weird and unsubstantiated miracles which have no linkage to the gospel of Jesus Christ. It must be known that any spectacle in Christianity detached from Christ can in no way be sustained in Christendom. Miracles and supernatural manifestation should not be envisaged as a revival; if it does not lead people to the cross of Jesus Christ wherewith men are saved.

\section{CONCLUSION}

The study attempted an explanation of what revival of religion is and how revival erupts amongst the EvangelicalPentecostal movements whiles not leaving behind the challenges associated with the breaking forth of revivals. The study findings highlight that, revivals conjointly originate from the Holy Spirit, through a prepared person. Both the prepared person and the Holy Spirit are requirements for revival to come to pass.

The study further evaluated some revivals of old and analyzed its impact as at then and how it culminated in

59 Rob Warner, Ecstatic Spirituality and Enterpreneurial Revivalism: Reflections on the Toronto Blessings In ON Revival - A Critical Examination.

${ }^{60}$ Kwasi Atta Agyapong, "An Evaluation Of Akan And Konkomba Witchcraft Trials \& Beliefs In Ghana : In Dialogue With The Biblical, Anthropological And Psychiatrists Perspectives," Pentecostalism, Charismaticism and Neo-Prophetic Movements Journal 1, no. 7 (2020): $92-102$. 
the effectiveness of Christianity in subsequent years. It was unraveled that, centuries after the most significant revivals in history, there were spiritual declensions. The study has made several recommendations to curtail the anomaly, where places that received divine presence (revival) became desolate in subsequent years as if nothing had transpired apart from the antique works penned for the next generations. The revival which is a great glee amongst Evangelical Pentecostal movements, when not managed with the necessary theological acumen and discernments from historical happenings breed challenges of which the next generation and beyond have to tussle with, in order to sustain the Christian faith. Additionally, revivals mostly come up against conflicting hegemonies of enlightenment, new age philosophies, postmodernism and other new and upcoming trends which appeal to most Evangelical-Pentecostal Movements. Efforts must be made to avert syncretistic tendencies as most persons are attracted so easily to new trends, whereby they can be easily encapsulated as if they are catalysts to revivals but end up making them ephemeral.

\section{ABOUT AUTHOR}

Kwasi Atta Agyapong, BTh, MA Pentecostal Studies, Research Associate, School of Theology and Missions, Pentecost University - Ghana and a Member of the American Anthropological Association. He is an Ordained Minister of The Church of Pentecost, and currently the District Minister for Nkawkaw Asuboni, Eastern Region, and Ghana. His areas of interest in academics are Biblical Studies, Witchcraft Studies, Pentecostal Studies, and Anthropology.

\section{BIBLIOGRAPHY}

Agyapong Kwasi A. "An Evaluation of Akan and Konkomba Witchcraft Trials \& Beliefs in Ghana: In Dialogue with the Biblical, Anthropological and Psychiatrists Perspectives" Pentecostalism, Charismaticism and NeoProphetic Movements Journal 1, no 7 (2020): 92-102. https://doi.org/10.38159/pecanep.2020121 .Beliefs in the Activities of Witchcraft in Ghana" E-Journal of Religious and Theological Studies -5th Anniversary Special Edition, no.6 (2020): 281-289 https://doi.org/10.38159/erats.2020092 . "Pastoral And Theological Responses To The Effects Of Witchcraft Beliefs In Ghana" E-Journal of Humanities and Social Sciences 1, no.6 (2020): 174-184. https://doi.org/10.38159/ehass.2020096

Anderson, Allan. An Introduction to Pentecostalism: Global Charismatic Christianity. Edinburgh: Cambridge University Press, 2004.

Anderson, Robert M. Vision of the Disinherited: The Making of American Pentecostalism. Peabody: Hendrickson, 1979.

Awstin (The Principal Western Mail Reporter). The Religious Revival in Wales. London: Revival Library Reprints, 1904.

Backholer, Mathew. Revival Fire: 150 Years of Spiritual Awakenings and Moves of the Holy Spirit Days of Heaven on Earth. Faith Media, 2013.

Burrell Gibson \& Morgan Gareth. Sociological Paradigms and Organisational Analysis. London:Heinemann Educational, 1979.

Bebbington, David W. Evangelicalism In Modern Britain: A History From the 1730s to the 1980s. London: Unwin Hyman Ltd., 1989.

Creswell, John W. Educational Research: Planning, Conducting and Evaluating Quantitative and Qualitative Research. 3rd ed. New Jersey: Pearsey Education, 2008.

Dickson, Roger E. Dickson Teachers Bible with Commentary and Encyclopedic Study Guide. Hutchinson, Kansas: African International Missions, 2010.

Dunn, James. Baptism in the Holy Spirit. Westminster: John Knox Press, 1970.

Edwards, Brian H. Revival! A People Saturated with God. Darlington: Evangelical Press, 1990.

Edwards, Joel. Evangelical Alliance: Euston Statement on the Toronto Blessing Reprinted in Calver, C. and Warner, R. 1996. Together We Stand. London: Hodderand Stoughton, 1994.

Green, Michael. I Believe in the Holy Spirit. Michigan: WM. B. Eerdmans Publishing Co, 2004.

Hird, Ed and Janice Hird. "An Analysis of Evan Roberts and the Social Impact of the 1904 Welsh Revival." Light Magazine, no. June (2019).

Jones, Martyn Lloyd. "Revival: ‘An Historical and Theological Survey'In How Shall They Hear ?" In Compiled Papers from the Puritan and Reformed Studies Conference. London, 1959.

Jones, Robert T. The Great Reformation. Leicester: Oxford, 1985.

Kinnear, Angus I. Against the Tide: The Story of Watcman Nee. Eastbourne: Kingsway, 1973.

Kusi, Hinneh. Doing Qualitative Research: A Guide for Researchers. Accra: Emmpong Press, 2012. 
Latham, Steve. On Revival: A Critical Examination. Carlisle, Cumbria: Paternoster Press, 2003.

Lord, Andy. "Pentecostal Mission Through Contextualization." Penteco Studies 1 (2011): 103-17.

McFarlene, Graham. The Role of the Holy Spirit. In On Revival: A Critical Examination. Carlisle, Cumbria: Paternoster Press, 2003.

Menzies, Robert W. Menzies \& Robert P. A Call to Evangelical Dialogue: Spirit and Power Foundations of Pentecostal Experience. Grand Rapids, Michigan: Zondervan, 2000.

Mock, Dennis J. Old Testament Survey. Atlanta: Zondervan, 1989.

Onyinah, Opoku. "The Movement of the Spirit Around the World in Pentecostalism." Transformation : An International Journal of Holistic Mission Studies 30, no. 273 (2013). https://doi.org/10.1177/0265378813503234.

Ortlund,Jr. Raymond C. Revival Sent From God:What the Bible Teaches for the Church Today. Leicester: IVP, 2000.

Prince, Derek. Baptism in the Holy Spirit. Whitaker House, 1995.

Stackhouse, Ian. Revivalism, Faddism and the Gospel In On Revival: A Critical Examination. Carlisle, Cumbria: Paternoster Press, 2003.

Ukachi, Austin C. "Marks of a Pentecostal Revival.” Sunday Magazine, 2016.

Wallis, Arthur. Rain From Heaven: Revivals In Scripture and Heaven. London: Sevenoaks Hodder and Stoughton, 1979.

Williams, Rodmans. Renewal Theology:Systematic Theology from a Charismatic Perspective. Virginia: Zondervan Academic, 2011.

Wright, Nigel. Does Revival Quicken or Deaden a Church? In On Revival : A Critical Examination. Carlisle, Cumbria: Paternoster Press, 2003.

Warner, Rob. Ecstatic Spirituality and Enterpreneurial Revivalism: Reflections on the Toronto Blessings In On Revival - A Critical Examination. Carlisle, Cumbria: Paternoster Press, 2003.

Waugh, Geoff. Revival Fire: History's Mighty Revivals. Renewal Journal, 2020 